\title{
Analysis of Production, Transport and Lifecycle of Pellets
}

\author{
Ricardo Díaz Martín ${ }^{1}$, Gaston Sanglier Contreras ${ }^{2}$, Adib Guardiola Mouhaffel ${ }^{3}$ \\ ${ }^{1}$ Chairman building Engineering department, CEU San Pablo University, Madrid, Campus de Monte príncipe \\ ${ }^{2}$ Associate professor building Engineering department, CEU San Pablo University, Madrid, Campus de Monte príncipe \\ ${ }^{3}$ CEU San Pablo University, Madrid, Campus de Monte príncipe
}

\section{Email address:}

Ricadima@ceu.es (R. D. Martín), Sanglier.eps@ceu.es (G. S. Contreras), aa.Guardiola@usp.ceu.es (A. G. Mouhaffel)

\section{To cite this article:}

Ricardo Díaz Martín, Gaston Sanglier Contreras, Adib Guardiola Mouhaffel. Analysis of Production, Transport and Lifecycle of Pellets. American Journal of Environmental Protection. Vol. 4, No. 2, 2015, pp. 91-94. doi: 10.11648/j.ajep.20150402.13

\begin{abstract}
The forestry production industry in the province of Galicia, represents one of the most available areas of biomass production in Spain. The aim of this study is determine the carbon footprint score in forestry production and processing of pellets for subsequent transportation to a community with little locally available biomass. The methodology proposed for processing forestry production and consumption, taking actual data, actual emissions in the area of Pontevedra, and considering fundamental aspects from the environmental point of view provides the most accuracy. The performance of machinery and consumption in the forestry process, as well as distance to be covered, ultimately give us the impact of the carbon footprint for comparison with predetermined targets in emissions savings.
\end{abstract}

Keywords: Carbon Footprint, Forestry Treatments, Transport, Pellets

\section{Introduction}

This article aims to explain the methodology based specifically on the life cycle analysis (LCA), which has been taken into account in order to determine the carbon footprint (CFP) for forestry production and transportation of pine wood pellets used as biomass for energy production. A quantitatively determined amount and percentage of CFP in the production and transportation of pine wood pellets used as fuel for thermal purposes in the Canaries is suggested.

At present, however, the ACV still have uncertainties about the risks: there are numerous methodologies capable of being applied o each case, leading to results which are, on many occasions, diverse and even contradictory [1]. It is important to that efforts to implement measures within sectors that are in transition due to the implementation of ISO 14001 systems, such as transport, agriculture, tourism, the residential sector, and where knowledge of the impact of CFP are causing themto change their attitude towards management and development for responsible and lasting business [6].

So that we can accurately characterize CFP in regards to production and transport, raise awareness and make improvements in moving away from the policies associated with "Greenwashing", will jump on the train by looking at products and sources of renewable energy which lack sufficient information for determining the impact of the product [6].

\section{Methodology}

For the evaluation of production, a system of forestry production of medium difficulty in terms of accessibility [8], the pine which has an average density of $460 \mathrm{~kg} / \mathrm{m}^{3}$ with humidity at the time of collection of around $50 \%$ has been taken into account. Once dried and pelletized, it is a wood that reaches a density of around $670 \mathrm{~kg} / \mathrm{m}^{3}$, on ready for commercialization.

As the combustion of bio-fuels (from biomass) is considered not to generate GHG emissions - their emission factor is zero. Therefore, the emission factor of fuel formed by the mixture of fossil fuels and bio-fuels will be the result of subtracting from the first, the extent to which is the second. The consideration of the emission during the drying period will correspond to supplementary accessories in the trammel

Ground transportation to Vigo and subsequently by sea to the port in Gran Canaria, and finally the trip along the length of the island, will give us the results of emissions using the coefficients applied in each case.

The quantification system in kilos of emission of carbon dioxide $\left(\mathrm{CO}_{2} \mathrm{Kg} / \mathrm{T}\right)$ will be given by the following methods, depending on the activity:

- Forestry production tasks will be determined by the equipment used and performance in obtaining a ton of wood [1]. 
- The drying treatment is carried out with a trammel fed with biomass fuel, so the emission rate will be compensated and only consider the purpose of issuing operating auxiliaries.

- The system is considered as pelletizing, pelletized at30 $\mathrm{kW}$ with a production rate of 0.5 tons $/ \mathrm{h}$, calculated by the emission power required by $\operatorname{Tn}[2]$.

- Land transport by mode of transport, loading and distance [2].

- Shipping, Kuehne + Nagel - the software will give us equates tonsduring the trip [4].

\section{Results}

\subsection{Forestry Production}

Forestry production during the maintenance of the forest environment requires a set of machines that maximize and ensure optimum functionality in the execution of tasks. The coefficients of work applied to the machinery required based on performance [1], will give the resulting emissions for obtaining pine wood.

Taking the density of the pine [8], we managed to obtain the total emissions of forestry production, which would be 98,65 $\mathrm{kg} \mathrm{CO}_{2} / \mathrm{T}$; treatment and management of pelletized wood would be $25,08 \mathrm{~kg} \mathrm{CO}_{2} / \mathrm{T}$
Table 1. $\mathrm{CO}_{2}$ emissions forestry pine production process.

\begin{tabular}{lll}
\hline Cut down trees sytem & Total $\mathrm{Kg} \mathrm{CO}_{2} / \mathbf{m}^{3}$ \\
\hline Hand saw machine & 7,88 & $\mathrm{~kg} \mathrm{CO} / \mathrm{m}^{3}$ \\
Jaw Crushing-wood chipper & 14,20 & $\mathrm{~kg} \mathrm{CO} 2 / \mathrm{m}^{3}$ \\
Transport & 16,80 & $\mathrm{~kg} \mathrm{CO}$ \\
Total & 38,88 & $\mathrm{KgCO}_{2} / \mathrm{m}^{3}$ \\
\hline
\end{tabular}

Table2. $\mathrm{CO}_{2}$ emissions Factory process.

\begin{tabular}{|c|c|c|}
\hline Factory process & $(\mathbf{K w})$ & Pollutantemissions \\
\hline Conveyorized & 18,00 & $1,44 \mathrm{Kg} \mathrm{CO}_{2} / \mathrm{m}^{3}$ \\
\hline Wood chipper & 15,00 & $1,20 \quad \mathrm{Kg} \mathrm{CO}_{2} / \mathrm{m}^{3}$ \\
\hline Sieve shaker & 11,00 & $0,88 \mathrm{Kg} \mathrm{CO} / \mathrm{m}^{3}$ \\
\hline Shredding machine & 19,00 & $1,52 \mathrm{Kg} \mathrm{CO}_{2} / \mathrm{m}^{3}$ \\
\hline Rotary -trammel dryers & 23,00 & $1,84 \mathrm{Kg} \mathrm{CO}_{2} / \mathrm{m}^{3}$ \\
\hline Pelletizing machine & 30,00 & $2,40 \quad \mathrm{Kg} \mathrm{CO}_{2} / \mathrm{m}^{3}$ \\
\hline Cooled and packed & 9,40 & $0,72 \mathrm{Kg} \mathrm{CO}_{2} / \mathrm{m}^{3}$ \\
\hline Total & & $10,03 \mathrm{Kg} \mathrm{CO} / \mathrm{m}^{3}$ \\
\hline
\end{tabular}

\subsection{Transport}

\subsubsection{Maritime Transport}

Using the software company Kuehne + Nagel [4], which calculates the carbon footprint of a load from the port of departure, Vigo, to the destination of Las Palmas, 22 tons of pellets could be loaded and including the weight of a foot container at $2.230 \mathrm{Kg}$.

\begin{tabular}{|l|l|l|l|l|l|l|l|}
\hline From & To & $\begin{array}{l}\text { Mode of } \\
\text { transport }\end{array}$ & $\begin{array}{l}\text { Distance } \\
\text { in } \mathrm{km}\end{array}$ & $\begin{array}{l}\text { lo2 } \\
\text { in } \mathrm{kg}\end{array}$ & $\begin{array}{l}\text { NOx } \\
\text { in } \mathrm{kg}\end{array}$ & $\begin{array}{l}\text { S02 } \\
\text { in } \mathrm{kg}\end{array}$ & $\begin{array}{l}\text { PM10 } \\
\text { in } \mathrm{kg}\end{array}$ \\
\hline VIGO, SPAIN (ESVGO) & $\begin{array}{l}\text { LAS PALMAS, SPAIN } \\
\text { (ESLPA) }\end{array}$ & Sea & 2,235 & 794.51 & 16.32 & 10.03 & 1.41 \\
\hline Total & & $\mathbf{2 , 2 3 5}$ & $\mathbf{7 9 4 . 5 1}$ & $\mathbf{1 6 . 3 2}$ & $\mathbf{1 0 . 0 3}$ & $\mathbf{1 . 4 1}$ \\
\hline
\end{tabular}

\begin{tabular}{|l|l|l|l|l|l|l|l|}
\hline From & To & $\begin{array}{l}\text { Mode of } \\
\text { transport }\end{array}$ & $\begin{array}{l}\text { Distance } \\
\text { in } \mathrm{km}\end{array}$ & $\begin{array}{l}\text { EC (TTW) } \\
\text { in GJ }\end{array}$ & $\begin{array}{l}\text { EC }(\mathrm{WTW}) \\
\text { in GJ }\end{array}$ & $\begin{array}{l}\text { CO2e (TTW) } \\
\text { in } \mathrm{kg}\end{array}$ & $\begin{array}{l}\text { CO2e (WTW) } \\
\text { in } \mathrm{kg}\end{array}$ \\
\hline VIGO, SPAIN (ESVGO) & $\begin{array}{l}\text { LAS PALMAS, SPAIN } \\
\text { (ESLPA) }\end{array}$ & Sea & 2,235 & 9.52 & 10.36 & 739.32 & 802.12 \\
\hline Total & & $\mathbf{2 , 2 3 5}$ & 9.52 & $\mathbf{1 0 . 3 6}$ & $\mathbf{7 3 9 . 3 2}$ & $\mathbf{8 0 2 . 1 2}$ \\
\hline
\end{tabular}

Figure 1. Footprint maritime transport,Vigo- Las Palmas.

Fuente: EmpresaKuehne+Nagel

\subsubsection{Land Transport}

$\mathrm{CO} 2$ emissions of diesel is $2.47 \mathrm{~kg} \mathrm{CO} 2 / 1$ [2], considering the necessary vehicle to carry the burden of $24,3 \mathrm{Tn}$ pellet, plus the weight of a 20-foot container, requires a power of 340 $\mathrm{CV}$ [3], with a consumption of 24 liters per $100 \mathrm{~km}$, the coefficient applicable to diesel is $0.6 \mathrm{~kg} \mathrm{CO} 2 / 1 \mathrm{Km}$ [3].

To calculate the carbon footprint of transporting the biomass, we will consider the path from start to finish, plus the auxiliary elements used in transport - in this case the dampening unit for conservation of biomass in the containers.

\subsubsection{Transport's Footprint Score}

The different modes of transport employed to mobilize biomass plus the system utilized to conserve moisture will form the elements that generate the emissions which determine the final size of the carbon footprint.

Table 3. $\mathrm{CO}_{2}$ transpots emissions.

\begin{tabular}{|c|c|c|c|c|}
\hline & & $(\mathbf{K m})$ & Emissions & Total transport emissions \\
\hline Trucker & Pontevedra-Vigo & $25,00 \mathrm{Km}$ & 0,60 Kg CO2/ litros Km & $15,00 \mathrm{Kg} \mathrm{C}_{2} / 24,3 \mathrm{~T}$ \\
\hline Ship & Vigo-Las Palmas & $2234,58 \mathrm{Km}$ & - & $802,12 \mathrm{Kg} \mathrm{CO}_{2} / 24,3 \mathrm{~T}$ \\
\hline Total & & & & $823,49 \mathrm{Kg} \mathrm{CO}_{2} / 24,3 \mathrm{~T}$ \\
\hline
\end{tabular}

The impact per ton in transport is $34,00 \mathrm{Kg} \mathrm{CO}_{2}$, where of the total. maritime transport accounts for $93 \%$ of emissions and land $7 \%$ 


\subsection{Schedule Carbon Footprint Production and Transportation}

from Vigo to Las Palmas of pinewood pellets: emissions are quantified in $193 \mathrm{~kg} \mathrm{CO}_{2} /$ per ton of biomass transported.

Figures for forest production, processing and transportation

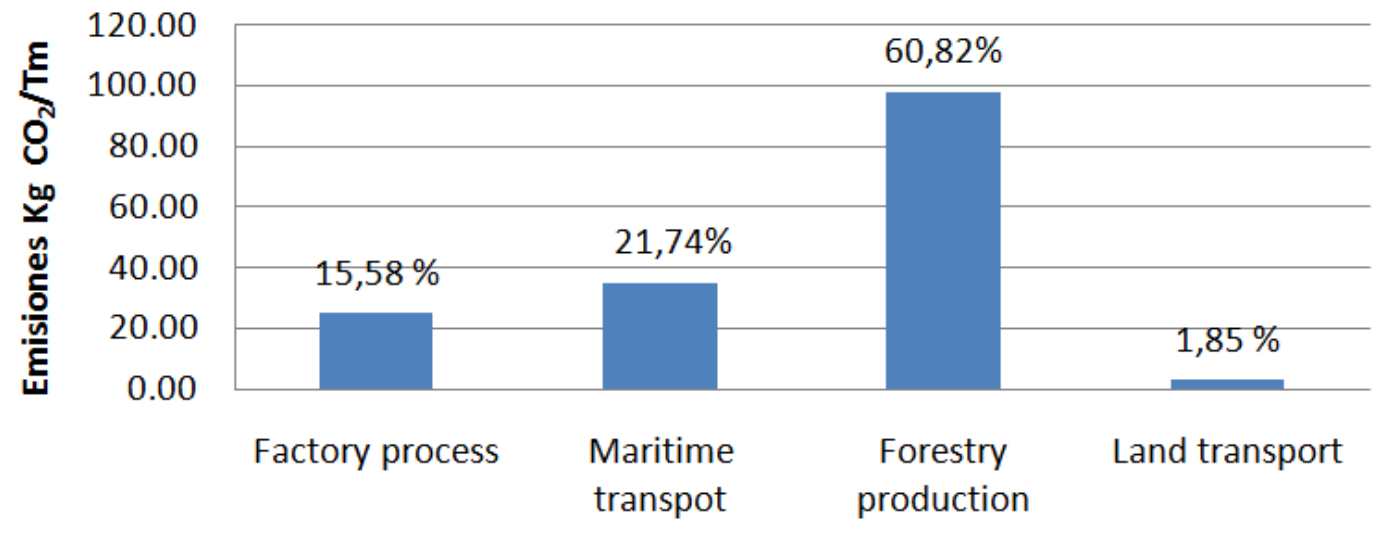

Figure 2. Distribution of carbon dioxide as activity during production and transportation of pine pellets.

\section{Conclusions}

Every ton of biomass consumed by thermal purposes is avoiding issuing $1.350 \mathrm{Kg} \mathrm{CO}_{2}$ of emission factors as with diesel [2] -where the system of production and transportation of biomass studied represents $13.42 \%$ of the emissions that they aim to save, and whose treatment and forestry production represent $8,17 \%$, with maritime transport $2,92 \%$.

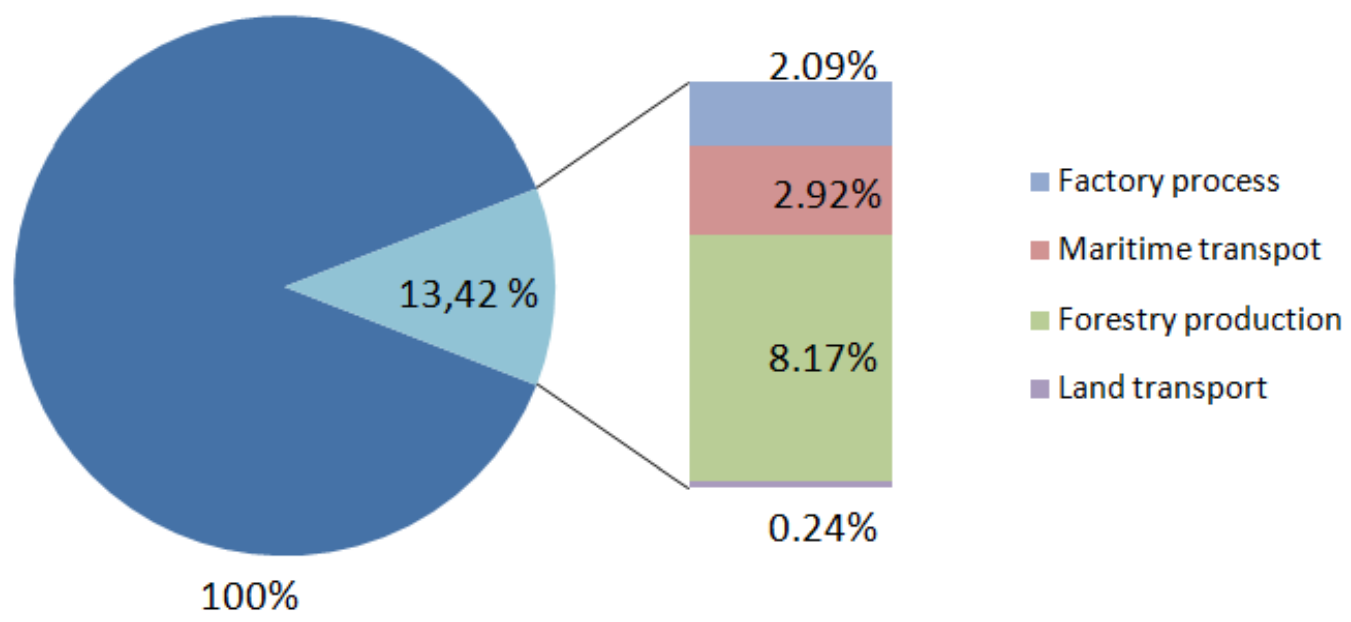

Figure 3. Distribution of carbon dioxide produced during the production and transport of pellets in total, which aims to save on these emissions per ton.

In the above, concepts have not been included that would suffer losses to biomass energy through inappropriate transportation conditions and adsorption of moisture during transport [5] in the case of pellets we would be trying to increase.

We propose as an upgrade to the negative impact of excessive emissions during transportation and avoidance of mismatches between the goals of emission reductions and emissions required to benefit from the use of biomass in areas minimal local resources [5]. A policy of energy crop planting of the paulownia type, where the terrain of the Canary Islands is ideal, should be implemented.

The return on investment for crop when used for the production of biomass for thermal purposes is high, especially as the machinery required for the operation is less robust and simpler, requiring less fossil fuels and improving the impact on tasks.

\section{Acknowledgements}

This work has been supported by Sedam Management and The Canary Islands Technological Institute. Oliver González Arias, Miguel Pérez Afonso, Gonzalo Pierna Vieja Izquierdo.

\section{References}

[1] L.A. Mohamed, M. Kouhila, S. Lahsasni, A. Jamali, A. Idliman, M Rhazi, M. Aghfir, M.Mahrouz. "Equilibrium moisture content and heat of sorption of Gelidiumsesquipedale". Journal of StoredProductsResearch. Vol. 41 No 2,pp. 199-209. 2005. 
[2] Estimación de la huella de carbono de productos forestales"DirecciónNacional de Industrias Ministerio de Industrias, Energía y Minería Consejo Sectorial Forestal-Madera Uruguay 2013.

[3] Guía para el cálculo de la huella de carbono y para la elaboración de un plan de mejora de una mejora de organización, Ministerio del medio ambiente 2014.

[4] La guía para la gestión del combustible, IDAE 2006.

[5] http://www.kn-portal.com/seafreight/environment/calculator.

[6] Díaz R., Contreras G., Guardiola A. "Comparación entre métodos estáticos y dinámicos de cálculo de humedad en biomasa”. Dyna energía y sostenibilidad Volumen 3 (1). 2014.

[7] P.MasAlique, F. HerraezGarrido,D. Muñoz Jimenez. "La huella de carbono como ventaja competitiva" Volumen 3 (1). 2014.
[8] Luis Ortíz, Alejandro Tejada, Antonio Vázquez."Aprovechamiento de biomasa forestal". Revista CIS-Madera. 17-32. 2003.

[9] Yolanda Ambosio. APROVECHAMIENTO DE BIOMASA FORESTAL: Maquinaria, sistemas de recogida, rendimientos y costes. Experiencias reales"E.U.I.T Forestal. Universidad Politécnicade Madrid.2009

[10] PAPENDIECK, S. 2010. La Huella de Carbono como Nuevo EstándarAmbiental en el Comercio Internacional de Agroalimentos:Informe Final. ATN/ME-9565-RG BIDFOMIN.

[11] SCHNEIDER, H. y SAMANIEGO, J. 2010. La huella del carbonoen la producción, distribución y consumo de bienes y servicios.Documento de Proyecto. Comisión Económica para América Latinay el Caribe (CEPAL). 